\title{
Ayurvedic Management of Trigeminal Neuralgia A Case Report with respect to Anantha Vata
}

\section{Case Report}

\section{Neethu Kesavan ${ }^{1}$, Sreekumar K Karunakaran ${ }^{2 *}$}

\author{
1. Final M.S (Ay) Scholar; 2. Assistant professor, Department of Shalakyatantra, \\ Govt. Ayurveda College, Tripunithura, Kerala, India.
}

\begin{abstract}
Trigeminal neuralgia is considered asthe most excruciatingly painful condition known to mankind. Due to the sharp, intense and stabbing nature of pain, sufferers called it as 'suicide disease'. The management of trigeminal neuralgia includes anticonvulsants, tricyclic antidepressants drugs and other surgical measures. As per Ayurvedic classics this condition has close proximity with the disease Ananthavata which is Sannipathika in nature. The name itself indicates the extremely vitiated vatadosha. The management explained by Acharya Susrutha is Siravedha and Vatapitha Samana. This article describes a case report of 64 years old lady presented with trigeminal neuralgia. In present study, it is observed that Ayurvedic management has provided significant relief in symptoms and found reduced recurrence. The post effective pain relief was found with Matravasthi and Shirovasthi.
\end{abstract}

Keywords: Trigeminal neuralgia, Ananthavata, Siravyadha, Matravasthi, Shirovasthi.

\section{Introduction}

Trigeminal neuralgia, also known as tic douloureuxis adisorder with prevalence of 4-5 per 100, 000 individuals and has a slightly higher incidence for women compared with men. It is one of the most painful condition occurs most often in people over the age of 50 years. Trigeminal neuralgia is defined by International Head ache Society as unilateral disorder characterized by brief electric shock like pain, abrupt in onset and termination, andlimited to the distribution of one or more divisions of trigeminal nerve.Pain usually starts from retroauricular region and spreads towards orbit, ear or to the chin. In infra- orbital neuralgia pain starts below the orbit and spreads towards nose, upper lip, or to the cheek (1). The pain resulting from Trigeminal neuralgia imposes a substantial burden on patients.

Medications often used to control the pain of trigeminal neuralgia include carbamazepine, phenytoin, gabapentine and clonazepam. The effective dose in newly diagnosed $\mathrm{TN}$ may be less than that required to treat epilepsy. Common initial side effects include drowsiness, nausea, dizziness, diplopia, ataxia etc. Other treatment modalities are peripheral neurectomy, gasserian ganglion injection, intracranial

\section{*Corresponding Author:}

\section{Sreekumar K}

Assistant Professor, Department of Shalakya Tantra,

Government Ayurveda College, Tripunithura,

Kerala, India

E-mail ID: drsreekumarmsayu@yahoo.co.in decompression of trigeminal ganglion etc.

In Ayurvedic literature, all conditions which can cause pain over the head are included in Siroroga(2). AcharyaSusrutha explained 11 Sirorogas and Ananthavata is one among them(3). The symptoms and pathogenesis of Ananthavata explained by the Acharya has close proximity with trigeminal neuralgia. Role of Ayurveda in curing some of these diseases are appreciable since it also compels the patient to avoid Nidana and to follow Pathyaahara and Vihara.

\section{Aims and Objectives}

To study the efficacy of Ayurvedic management in trigeminal neuralgia with special reference to Ananthavata.

\section{Materials and Methods}

A 64 year old female patient of trigeminal neuralgia was selected from OPD, Department of Salakyatantra, Govt Ayurveda College, Tripunithura, Kerala, India.

\section{Literature Review}

Trigeminal nerve is a paired mixed cranial nerve which has three main branches; ophthalmic, maxillary and mandibular nerve(4). Trigeminal neuralgia is one of the most painful conditions affecting this nerve. One, two or all the branches may be affected. Mostly middle and the lower branches are involved. The ophthalmic division alone is involved in less than $5 \%$ of cases. Usually occurring unilateral, only $10-12 \%$ cases have bilateral involvement. The pain is felt in the areas where 
these branches are supplied ie ear, eye, lips, nose, forehead, teeth, cheeks etc. The pain is characterized by episodes of intense pain lasts for seconds to minutes. The triggers of pain attacks includes chewing, talking, drinking, touching, blowing the nose, shaving, brushing, wind exposure etc.

The single attack generally lasts from less than a second to a few seconds, but it may present in clusters of variable intensity with up to 2 minutes duration. Severity of pain is correlated with reduced measures of daily functioning, quality of life, well - being, sleep and overall health status. Evidence has been mounting that in a large proportion of cases, compression of the trigeminal nerve at or near the dorsal root by a blood vessel is a major causative or contributing factor. The management of trigeminal neuralgia includes anticonvulsants, tricyclic antidepressants drugs. If medical management fails rhizotomy (nerve fibres are damaged to block pain), balloon compression, glycerol injection, radiofrequency ablation, microvascular decompression etc are selected based on condition of the patient.

Based on the symptoms of trigeminal neuralgia, it can be correlated to Ananthavata. It is a disease in which tridoshas vitiate the manyaor greevaparswa and produces severe intolerable pain at the back of neck, in the eye ball, frontal region, root of nose and in temporal region. it also causes hanugraha, netrarogas and gandaparswakampa(5). So it is clear that there is involvement of three branches of trigeminal nerve here.

Some Acharyas not mentioned this disease in Shirorogas for having similarity with Anyatovata explained in Sarvagatanetraroga(6). Anyatovata is a Vatapradhana disease in which eye problems are the main features. Vatahara and netrabrimhanachikitsa should be done there. Thus ophthalmic branch of trigeminal nerve is involved there.

Treatment of Ananthavata is explained similar as that of Suryavartha. In Suryavartha, Nasyakarma, Lepa, Parisheka, Kabalagraha, Shirovasthietc are advised. Food processed with large quantity of milk and ghee are also included. As similar in Ananthavata, A hara which is Vatapithasamana is explained. Siravyadhana is the main sodhana procedure mentioned here(7).

\section{Case Study}

A 64 year old lady with known history of HTN approached the OPD, presented with severe unilateral pain over right side of face since 8 years.

\section{Chief Complaints and Associated Symptoms}

The pain was twitching innature; over right temporal, frontal, cheeks, lower lid, jaw region. The jaw movements were restricted due to pain. It was brief but excruciating which comes in repeated flashes. The episodes of pain aggravates on exposure to cold, wind, on physical as well as mental exertion. During the episode, the pain triggers with chewing, yawning, brushing teeth, washing the face etc.

\section{History of Present Illness}

The patient was suffering from these symptoms since 8 years. She was consulted in a local hospital and took an injection and some medicines for the same; attained temporary relief. Meanwhile hypertension was diagnosed and started medication. Initially these episodes were very brief and 2-3 times per week. As the patient was working in an ice factory, the heavy exposure of cold gradually increased the severity of symptoms. Thereafter patient underwent Homeopathic medication for 3 years and got mild relief. For further betterment she was admitted here for Ayurvedic management. Dental and neurological examination was done. Blood reports and CT scan of head and paranasal sinuses were normal.

\section{General Examination}

Weight $-62 \mathrm{~kg}$

Height $-165 \mathrm{~cm}$

Heart rate $-83 / \mathrm{min}$

Pulse rate- $78 / \mathrm{min}$

\section{Personal History}

Diet - mixed (mostly non veg)

Appetite - good

Bowel - regular

Micturition - normal

Sleep - disturbed

\section{Family History}

No relevant family history

\section{Investigations}

$\mathrm{Hb}-11.5 \mathrm{gm} \%$

ESR- $25 \mathrm{~mm} / \mathrm{hr}$

BP- $140 / 100 \mathrm{mmHg}$

\section{Diagnosis}

Ananthavata (Trigeminal neuralgia)

\section{Line of Management}

1.Deepana with Vaiswanara Churna(8) - 3 days

2.AcchaSnehapana with Rasnadasamoolagritham(9)

- Uthamamatra

3.Abyangaand Swedana 2 days

4.Virechana with Gandharverandataila- $25 \mathrm{ml}$ with milk, morning 6 am

5.Nasya with Varanadiksheeragritha $(10)$

6.Sirodharawith Mahanarayanataila(11)

7.Matravasthi with Dhanwantarammezhupakam(12)

8.Sirovasthiwith Uthamatailam(13)

The patient was instructed to avoid Ratrijagarana, cold exposure, cold intake, Vatavardhakaahara.

\section{Observation \& Result}

The patient got moderate relief from the symptoms after the treatment. The effect of treatment maintained during the pathyakala. She had given Rasnadasamoolagritha 10 gm HS as discharge medicine. The follow up was taken after 6 months which showed that patient was free from the symptoms. Patient had not experienced such a pain since 4 years after the treatment. Symptoms graded with VAS scale from 0 - 10. 
Table 1: Showing the results

\begin{tabular}{|l|c|c|c|c|}
\hline Symptoms & BT & AT & FU 6 & FU 1 \\
\hline $\begin{array}{l}\text { Pain over face, } \\
\text { temple, forehead }\end{array}$ & 10 & 4 & 0 & 0 \\
\hline $\begin{array}{l}\text { Restricted jaw } \\
\text { opening }\end{array}$ & 6 & 2 & 0 & 0 \\
\hline Pain over eyes & 8 & 2 & 0 & 0 \\
\hline
\end{tabular}

BT-Before Treatment; AT - After treatment; FU 6 -

Follow up after 6 months; FU 1 - Follow up after 1 year

\section{Discussion}

As per Ayurveda classics, in Sirorogadhyaya, visesharogas likeSuryavartha, Ardhavabedaka, Ananthavataetc are explained. All these are said to be Sannipathikaaccording to AcharyaSusrutha. While assessing the symptom, Suryavartha and Ardhavabedaka are found to be Pithapradhanasannipathika and Ananthavata is Vatapradhanasannipathika. Here in Ananthavata, most of the symptoms supports the involvement of vata. Increased Rookshaand Sheethaguna of Vatacauses pain.Chalaguna of vata is deranged and causes Hungrahaand Gandaparswakampa.

Here the patient had chronic history of indulgence in Theekshnaushnaaharaseva, heavy exposure to cold. Even though there is Tridoshadushti, the role of Vata and Pitha are more appreciable. The role of Kapha is negligible even though the disease situates in Kaphasthana.Siravedha is explained as main Sodhana. Rakta mokshacauses temporary reduction of venous pressure and it further releases the pressure over trigeminal nerve and reduces pain. It can be performed in acute pain.

The Chikitsa aims mainly pacification of Vata with associated Pittha.After Deepana, Pachana, and Dehasodhana, Sthanikachikitsa done with Varanadiksheeragrithanasya. Patient got relief after Nasya karma. Sirodharawas done to attain vatasamanatva and brimhana.Ultimately $V$ atahas to be tackled and the treatment will be complete only with Sthanikasodhana ofVataieVasthikarma. Hence the recurrence of the disease can be prevented.

\section{Conclusion}

Ayurvedic management has proved that it has a significant role, in reducing the symptoms of Trigeminal neuralgia as well as preventing the recurrence and complications.

\section{References}

1. SyamalKumar De. Fundamentals of Ear, Nose, Throat and Head- neck surgery. $9^{\text {th }}$ ed. The new central book agency (P) Ltd, London; 376p.

2. Madhavakara. Madhavanidana with madhukosavyakhyana. Sri Yadhunandanopadhyaya. Siroroganidanam. Chaukhamba Sura Bharati Prakashana, Varanasi; 392p.

3. Susrutha. SusruthaSamhita with Nibandhasangraha
Commentary of Sri Dalhanacharya and NyayachandrikaPanjika of Sri Gayadasacharya. Utharatantra Chapter 25/1. edited by Yadavji Trikamji Acharya. reprint ed. Varanasi.ChaukhambaSurabharatiPrakashan; $654 \mathrm{p}$.

4. Lange. Current Diagnosis \& Treatment in Otolaryngology- Head \& Neck Surgery. edited by Anil. K. Lalwani $3^{\text {rd }}$ ed. McGraw Hill Companies; 38p.

5. Susrutha. SusruthaSamhita with Nibandhasangraha Commentary of Sri Dalhanacharya and NyayachandrikaPanjika of Sri Gayadasacharya Utharatantra Chapter 25/ 14. edited by YadavjiTrikamjiAcharya. reprint ed. Varanasi ChaukhambaSurabharatiPrakashan;655p.

6. Susrutha.SusruthaSamhita with Nibandhasangraha Commentary of Sri Dalhanacharya and Nyayachandrika Panjika of Sri Gayadasacharya edited by Yadavji TrikamjiAcharya Utharatantra Chapter 6/27. reprint ed. Varanasi ChaukhambaSurabharatiPrakashan;605p.

7. Susrutha. SusruthaSamhita with Nibandhasangraha Commentary of Sri Dalhanacharya and NyayachandrikaPanjika of Sri Gayadasacharya edited by YadavjiTrikamjiAcharya Utharatantra Chapter 26/37. reprint ed. Varanasi ChaukhambaSurabharatiPrakashan; 658p.

8. Vagbata. Ashtangahridayam with Sarvangasundhara Commentary of Arunadatta.edited by HarisadasivaSasthri. Chikitsasthana Chapter 14/ 34. ChaukambaSanskitSansthan Varanasi reprinted 2009; 687p.

9. Vagbata.Ashtangahridayam with Sarvangasundhara Commentary of Arunadatta Chikitsa sthana Chapter 3/6. edited by Harisadasiva Sasthri. Chaukamba Sanskit Sansthan Varanasi reprinted 2009; 585p.

10. Vagbata.Ashtangahridayam with Sarvangasundhara Commentary of Arunadatta Uthara sthana Chapter 24/5. edited by Harisadasiva Sasthri. Chaukamba Sanskit Sansthan Varanasi reprinted 2009; 861p.

11. Sahasrayogam/

Chikitsasarasarvaswam.Sujanapriya vyakhyanam. $34^{\text {th }}$ ed.Vidyarambam Alapuzha; 299p.

publishers

12. Sahasrayogam/

Chikitsasarasarvaswam.Sujanapriya vyakhyanam. $34^{\text {th }}$ ed.Vidyarambam Alapuzha; 286p.

publishers

13. Sahasrayogam/

Chikitsasarasarvaswam.Sujanapriya vyakhyanam. $34^{\text {th }}$ ed. Vidyarambam publishers Alapuzha; 278p. 